Article

\title{
Nypa fruticans Wurmb. Vinegar's Aqueous Extract Stimulates Insulin Secretion and Exerts Hepatoprotective Effect on STZ-Induced Diabetic Rats
}

\author{
Nor Adlin Yusoff ${ }^{1,2, *}$, Vuanghao Lim ${ }^{1}$ (D), Bassel Al-Hindi ${ }^{2}$ (D), Khairul Niza Abdul Razak ${ }^{2}$, \\ Tri Widyawati ${ }^{3}$, Dwi Rita Anggraini ${ }^{4}$, Mariam Ahmad ${ }^{2}$ and Mohd Zaini Asmawi ${ }^{2}$ \\ 1 Integrative Medicine Cluster, Advanced Medical and Dental Institute, Universiti Sains Malaysia, Bertam, \\ Kepala Batas, Penang 13200, Malaysia; vlim@usm.my \\ 2 School of Pharmaceutical Sciences, Universiti Sains Malaysia, Penang 11800, Malaysia; \\ basselalhindi@yahoo.com (B.A.-H.); niza@usm.my (K.N.A.R.); mariam@usm.my (M.A.); \\ amzaini@usm.my (M.Z.A.) \\ 3 Pharmacology and Therapeutic Department, Medical Faculty, Universitas Sumatera Utara, \\ Medan 20155, Indonesia; tri.widyawati@usu.ac.id \\ 4 Anatomy Department, Medical Faculty, Universitas Sumatera Utara, Medan 20155, Indonesia; \\ dwirita@usu.ac.id \\ * Correspondence: noradllinyusoff@usm.my; Tel.: +604-562-2423
}

Received: 3 July 2017; Accepted: 10 August 2017; Published: 23 August 2017

\begin{abstract}
Background: An aqueous extract (AE) of vinegar made from Nypa fruticans Wurmb. can improve postprandial glucose levels in normoglycaemic rats. The aim of this study was to evaluate its antihyperglycaemic activity further using in vivo and in vitro approaches. Methods: AE was administered to streptozotocin (STZ)-induced diabetic rats twice daily at three doses $(1000,500$, and $250 \mathrm{mg} / \mathrm{kg}$ b.w.) for 12 days p.o. Several biochemical analyses and a histological study of the pancreas and liver were performed, accompanied by a cell culture assay. Results: As compared to diabetic control (DC), AE at the doses of 500 and $1000 \mathrm{mg} / \mathrm{kg}$ b.w. caused significant reduction $(p<0.05)$ of blood glucose, total cholesterol and triglycerides levels, with positive improvement of serum insulin levels. Interestingly, immunohistochemical staining of the pancreas suggested no $\beta$-cell regeneration, despite significant increase in insulin production. AE-treated groups, however, showed overall restoration of the hepatic histoarchitecture of STZ-induced liver damage, suggesting a possible hepatoprotective effect. The pancreatic effect of AE was further studied through RIN-5F cell culture, which revealed a positive stimulatory effect on insulin release at a basal glucose concentration $(1.1 \mathrm{mM})$. Conclusion: Nypa fruticans Wurmb. vinegar's aqueous extract exerts its antihyperglycaemic activity, at least in part, through insulin stimulatory and hepatoprotective effects.
\end{abstract}

Keywords: antihyperglycaemic; hepatoprotective; Nypa fruticans Wurmb.; vinegar; diabetes; RIN-5F; natural product

\section{Introduction}

Functional foods have captured considerable interest as potential alternative therapies for the treatment of diabetes mellitus (DM) and its complications [1-4]. Incorporating functional foods in the dietary regimen of diabetic patients proved to favourably influence the blood glucose levels of such patients [5-7]. According to the Functional Food Center, USA, functional foods are defined as natural or processed foods that contain known or unknown biologically active compounds which in defined, effective and nontoxic amounts provide a clinically proven and documented health benefit for the 
prevention, management, or treatment of a chronic disease [8]. Besides having minimal side effects in clinical practices and being obtainable at a relatively low cost, functional foods have garnered further attention due to the increase in scientific studies regarding their effectiveness.

Vinegar is one of the widely consumed functional foods worldwide. The consumption of vinegar with meals was used as a home remedy for diabetes before the advent of pharmacological glucose-lowering drugs [9]. Nypa fruticans Wurmb. vinegar locally known as nipa palm vinegar (NPV) is one of the traditional vinegars produced by fermentation of nira, the sap of the nipa palm (Nypa fruticans Wurmb.). It is predominantly consumed by populations in East Asia. In our previous study, an aqueous extract (AE) of NPV showed the strongest blood glucose lowering activity among several tested NPV extracts [10]. In another investigation dealing with the mechanisms of the antihyperglycaemic action of $\mathrm{AE}$, a significant effect was revealed in terms of alleviating postprandial hyperglycaemia in normolgycaemic rats [11].

The liver and the pancreas are two vital regulatory organs for glucose homeostasis. Abnormalities in both are strongly associated with the prevalence and progression of diabetes mellitus [12-14]. Several researches have demonstrated the positive effect of vinegars (i.e., balsamic, apple cider, and pineapple) in stimulating insulin secretion, improving the function of pancreatic $\beta$ cells [15], and protecting the liver cells $[16,17]$. Hence, the present study was designed to evaluate the possible effects of Nypa fruticans Wurmb. vinegar's aqueous extract on the pancreas and the liver using in vivo and in vitro approaches.

\section{Materials and Methods}

\subsection{Chemicals}

D-Glucose and streptozotocin (STZ) were purchased from Sigma Aldrich (St. Louis, MO, USA). Insulin ELISA kit was obtained from Crystal Chem, Inc. (Downers Grove, IL, USA). Metformin (Glucophage ${ }^{\circledR}$ ) was purchased from Bristol-Myers Squibb Co. (New York, NY, USA). All other chemicals and solvents used were of reagent grade.

\subsection{Vinegar Preparation and Extraction}

NPV used in the study was supplied by a local producer from Titi Bakong, Yan, Kedah, Malaysia $\left(5^{\circ} 48^{\prime} 9.42^{\prime \prime} \mathrm{N}, 100^{\circ} 22^{\prime} 35.32^{\prime \prime}\right.$ E). Several parts of nipa palm were authenticated and voucher specimens (USM.Herbarium 11541) were deposited at the Herbarium Unit, School of Biological Sciences, Universiti Sains Malaysia (USM). NPV was extracted using a liquid-liquid extraction method as described by Qiu et al. [18] with minor modifications. NPV $(500 \mathrm{~mL})$ was concentrated to a final volume of $250 \mathrm{~mL}$ at $37^{\circ} \mathrm{C}$ using a vacuum rotary evaporator (Buchi Labortechnik, AG CH-9230, Flawil, Switzerland). Concentrated NPV was first extracted with ethyl acetate at a ratio of 1:1. The ethyl acetate layer (upper layer) was then separated; the residue was collected and considered as the aqueous layer. The aqueous layer was concentrated under reduced pressure at $40{ }^{\circ} \mathrm{C}$ using a vacuum rotary evaporator; and was lyophilized using a freeze-drier (Labconco Corporation, Kansas, MO, USA) to yield $\mathrm{AE}$ (yield $85 \%$ ). AE was stored in the freezer at $-4{ }^{\circ} \mathrm{C}$ until further use.

\subsection{Experimental Animals}

Adult male Sprague-Dawley rats weighing 200 to $250 \mathrm{~g}$ were obtained from the Animal Research and Service Centre, Universiti Sains Malaysia (USM). All animals were housed and acclimatized in a well-ventilated animal transit room ( $12 \mathrm{~h}$ light $/ 12 \mathrm{~h}$ dark cycle) at the School of Pharmaceutical Sciences, USM. Throughout the experiment, the rats had ad libitum access to water and food pellets (Gold Coin Feedmills, Butterworth, Malaysia). The study protocol (depicted in Figure 1) was approved by the Animal Ethic Committee at USM (Approval number: USM/Animal Ethics Approval/2011/(71) (326)). Diabetes was induced chemically in rats using STZ via the intraperitoneal (i.p.) route at a dose 
of $55 \mathrm{mg} / \mathrm{kg}$ b.w. (body weight). Three days after injection, the animals whose fasting blood glucose levels were within the range of $11-20 \mathrm{mmol} / \mathrm{L}$ were selected for the study.

\subsection{Antihyperglycaemic Test of Different Doses of $A E$}

A total of 36 normal rats were used and randomly divided into 6 groups of 6 rats each. The assigned groups were as follows; Group 1: Normal control (NC) + distilled water (10 mL/ kg b.w), Group II: Diabetic control (DC) + distilled water (10 mL/kg b.w.), Group III: Diabetic + Metformin (500 mg/kg b.w.), Group IV: Diabetic + AE (1000 mg/kg b.w.), Group V: Diabetic + AE (500 mg/kg b.w.) and Group VI: Diabetic + AE ( $250 \mathrm{mg} / \mathrm{kg}$ b.w.). The oral treatments were given twice daily, with a 12-h dosing interval for a period of 12 days. Blood glucose levels were recorded on days 0, 3, 6, 9 and 12 following an overnight fast. At the end of the study the rats were euthanized, and blood samples were collected via cardiac puncture for insulin and lipid profile analyses. An insulin analysis was performed using an ELISA kit (Ultra Sensitive Rat Insulin, Crystal Chem, Inc., Downers Grove, IL, USA), whereas the lipid profile was estimated by enzymatic kinetic methods using an automated chemistry analyser (Siemens ADVIA 2400, Siemens Healthcare, Germany. The pancreas and the liver were excised for histological studies.

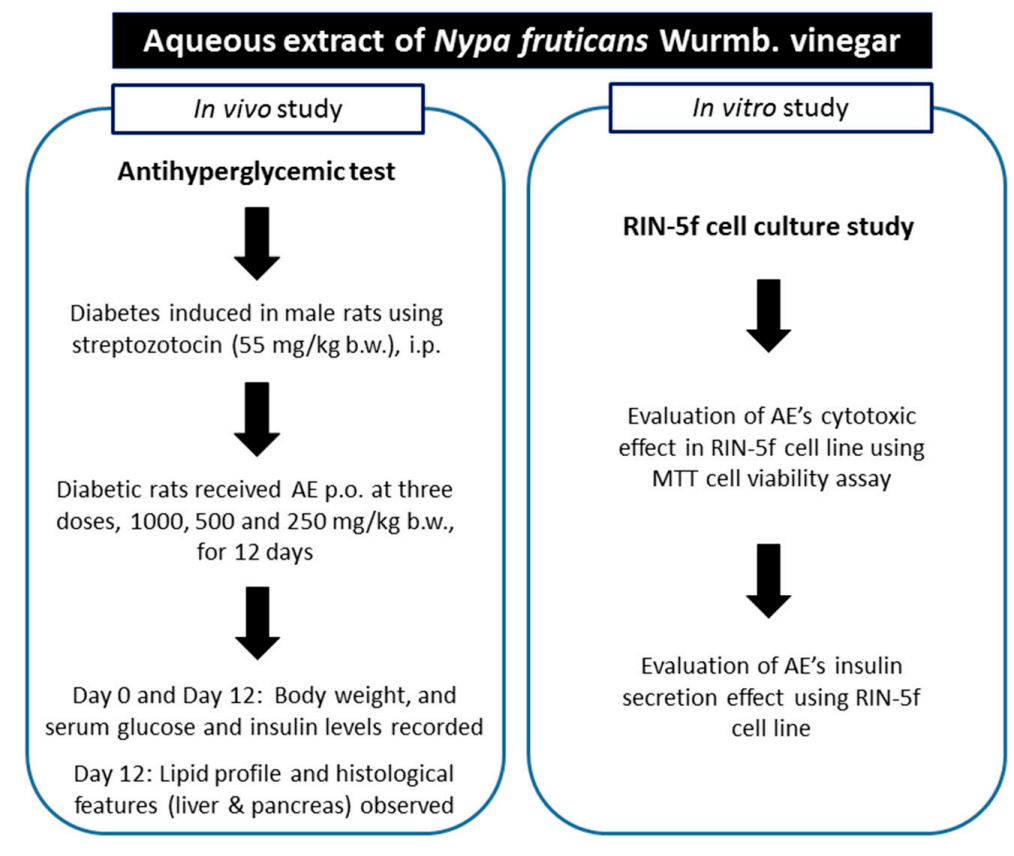

Figure 1. Overview of the experimental design.

\subsection{Pancreatic Immunohistopathological Study}

The pancreatic tissues were fixed in 10\% buffered formalin, processed using a tissue processor, Citadel 1000 histokinette (Shandon Scientific Ltd., Cheshire, UK) and embedded in paraffin using Histo-Center II-N (Barnstead/Thermolyne Corp., Dubuque, IA, USA). The paraffin-embedded tissues were sectioned into 5- $\mu \mathrm{m}$ slices and mounted on a poly-L-lysine-coated microscope slide. Immunohistochemical staining was performed using guinea-pig polyclonal antibody of rat insulin (DAKO, Glostrup, Denmark). The sections were deparaffinised. Endogenous peroxidises were quenched by treatment with $3 \%$ hydrogen peroxide in methanol, followed by washing in phosphate buffered saline (PBS). Then, the sections were incubated in a diluted normal serum for 20 min to block the non-specific binding of immunoglobulin G lgG. The primary antibody, guinea pig polyclonal insulin antibody (DAKO, Glostrup, Denmark) was applied for $30 \mathrm{~min}$, followed by washing with PBS for $5 \mathrm{~min}$. The sections were incubated for $30 \mathrm{~min}$ with the 1'biotinylated secondary antibody, 
followed by washing. Following a further 30-min incubation period in a Vectastain ABC kit (Vector Laboratories, Burlingame, CA, USA), washing was performed for $5 \mathrm{~min}$ before diaminobenzidine (DAB) (DAKO, Glostrup, Denmark was added for 3-5 min. The sections were lightly counterstained with Harris Haematoxylin, dehydrated, cleared and mounted. The islets of Langerhans were examined under a light microscope (Leica ${ }^{\circledR}$ DMi1, Leica Microsystems, Wetzlar, Hesse, Germany). The digital images were analysed using an image analyser (Leica ${ }^{\circledR}$ microsystem Qwin plus) to allow the calculation of the insulin-containing area of $\beta$ cells (\%) over the total area of the Langerhans islet.

\subsection{Histological Study of Liver}

Liver tissues were fixed, processed and embedded as mentioned in Section 2.5. Then, paraffin embedded 5- $\mu \mathrm{m}$ tissue sections were cut using a Reichert-Jung Histocut 820 II microtome (Cambridge Instrument $\mathrm{GmbH}$, Nussloch, Germany). The sections were stained with Haematoxylin and Eosin (H \& E) [19].

\subsection{RIN-5F Cell Culture}

The RIN-5F $\beta$ cell line was purchased from ATCC, Mannasas, USA (ATCC ${ }^{\circledR}$ CRL2058 ${ }^{\mathrm{TM}}$ ). The cell line was maintained in an RPMI 1640 medium containing $4.5 \mathrm{~g} / \mathrm{L}$ D-glucose, $1.5 \mathrm{~g} / \mathrm{L}$ sodium bicarbonate, $1 \mathrm{mM}$ sodium pyruvate, $10 \mathrm{mM}$ HEPES and $300 \mathrm{mg} / \mathrm{L}$ L-glutamine (Gibco A10491-01). The medium was supplemented with $10 \%$ foetal bovine serum (FBS) and $1 \%$ penicillin-streptomycin mixtures. The cell line was incubated at $37{ }^{\circ} \mathrm{C}$ with $5 \% \mathrm{CO}_{2}$.

\subsubsection{Cytotoxicity Assay}

The cytotoxic effect of AE on RIN-5F cells was analysed using an MTT (MTT: 3-(4,5-dimethylthiazol-2-yl)-2,5-diphenyltetrazoliumbromide) assay by measuring the reduction of MTT to formazan [20]. The cells were seeded in a 96-well plate at $1 \times 10^{4}$ cells/well and incubated in a $\mathrm{CO}_{2}$ incubator at $37^{\circ} \mathrm{C}$ for $72 \mathrm{~h}$. They were exposed to AE at the following concentrations of 100,50 , $25,12.5,6.25$ and $3.125 \mu \mathrm{g} / \mathrm{mL}$ for $24 \mathrm{~h}$. After a 24-h exposure, the medium was removed and washed with PBS. Twenty microliters of the MTT solution $(5 \mathrm{mg} / \mathrm{mL})$ were added to each well and the cells were incubated in the dark for $4 \mathrm{~h}$ more. Thereafter, the medium was removed, and the formazan crystal was dissolved with $100 \mu \mathrm{L}$ DMSO for $1 \mathrm{~h}$. Lastly, absorbance was measured at $570 \mathrm{~nm}$ using a microplate reader.

\subsubsection{Insulin Assay}

Insulin secretion was measured as previously described by Hassan et al. [21] with minor modifications. The cells were seeded in a 24-well plate at a density of $4 \times 10^{5}$ cells / well and incubated in a $\mathrm{CO}_{2}$ incubator at $37^{\circ} \mathrm{C}$. The medium was removed after $72 \mathrm{~h}$; and traces of the culture medium were washed off with PBS ( 3 times). The cells were pre-incubated for $40 \mathrm{~min}$ at $37^{\circ} \mathrm{C}$ with $1 \mathrm{~mL}$ of the Krebs Ringer Bicarbonate (KRB) buffer, containing $115 \mathrm{mM} \mathrm{NaCl}, 4.7 \mathrm{mM} \mathrm{KCl}, 1.28 \mathrm{mM} \mathrm{CaCl}_{2}, 1.2 \mathrm{mM}$ $\mathrm{Mg}_{2} \mathrm{SO}_{4}, 1.2 \mathrm{mM} \mathrm{KH}_{2} \mathrm{PO}_{4}, 10 \mathrm{mM}$ HEPES and $24 \mathrm{mM} \mathrm{NaHCO}_{3}$ (pH 7.4). The buffer was then replaced with $1 \mathrm{~mL} \mathrm{KRB} \mathrm{buffer} \mathrm{solution} \mathrm{supplemented} \mathrm{with} 1.1 \mathrm{mM}$ glucose in the absence/presence of AE $(25,12.5$ or $6.25 \mu \mathrm{g} / \mathrm{mL})$ and glibenclamide $(0.988 \mu \mathrm{g} / \mathrm{mL}, 9.88 \mu \mathrm{g} / \mathrm{mL}$ and $98.8 \mu \mathrm{g} / \mathrm{mL})$. The test was performed by incubating the cells for $30 \mathrm{~min}$ at $37^{\circ} \mathrm{C}$. Following incubation, aliquots were collected from each well for an insulin assay conducted using an ELISA kit according to the manufacturer's protocol (Cloud-Clone Corp., Katy, TX, USA).

\subsection{Statistical Analysis}

Data was expressed as the mean \pm standard error of the mean (S.E.M). The results were analysed using one-way analysis of variance (ANOVA) followed by Dunnett's comparison test. The results were statistically significant at $p<0.05$. 


\section{Results}

\subsection{Effect of Repeated Oral Administration of AE on Fasting Blood Glucose, Serum Insulin and Body Weight}

The effects observed after the 12-day twice-daily oral administration of AE on the levels of blood glucose, serum insulin and body weight in STZ-induced diabetic rats are presented in Table 1. Administered at 250,500, and $1000 \mathrm{mg} / \mathrm{kg}$ b.w., AE showed a dose-dependent effect as maximum blood glucose reduction was observed in the diabetic rats treated with the highest dose $(1000 \mathrm{mg} / \mathrm{kg} \mathrm{b.w.),}$ followed by those treated with $500 \mathrm{mg} / \mathrm{kg}$ b.w. The reduction in blood glucose for the two doses was at $49.2 \%$ and $56.6 \%$, respectively. AE at the dose of $250 \mathrm{mg} / \mathrm{kg}$ b.w. failed to normalize the blood glucose levels of diabetic rats after 12 days of treatment. Metformin, given at the dose of $500 \mathrm{mg} / \mathrm{kg} \mathrm{b.w.,}$ lowered blood glucose levels by $47.0 \%$ and $57.9 \%$ at the end of study, as compared with the respective initial value (day 0 ) and the value for DC on day 12 , respectively.

Distinct from its effect on blood glucose levels, STZ caused significant decreases in serum insulin levels as shown when comparing DC with NC on day $0(48.6 \% ; p<0.001)$. The administration of $\mathrm{AE}$ at three doses did not cause any significant increase in the serum insulin levels of diabetic treated rats, as compared with DC. Compared with day $0,500 \mathrm{mg} / \mathrm{kg}$ b.w. of AE, however, recorded significant improvement in the insulin level on day $12(13.6 \%, p<0.05)$.

As predicted, DC rats recorded a significant loss of body weight compared to its initial value and the value of NC on day 12 ( $p<0.01$ and $p<0.001$, respectively). The metformin-treated group only experienced mild and insignificant weight loss by the end of the study (day 12). AE-treated groups were comparable to DC as well in terms of body weight by the end of the study with no significant loss or gain recorded.

Table 1. Effect of twice daily oral administration of different doses of AE for 12 days on blood glucose level, serum insulin level and body weight of STZ-induced diabetic rats.

\begin{tabular}{|c|c|c|c|c|c|c|}
\hline \multirow{2}{*}{ Group } & \multicolumn{2}{|c|}{ Blood Glucose (mmol/L) } & \multicolumn{2}{|c|}{ Serum Insulin $(\mu \mathrm{g} / \mathrm{L})$} & \multicolumn{2}{|c|}{ Body Weight (g) } \\
\hline & Day 0 & Day 12 & Day 0 & Day 12 & Day 0 & Day 12 \\
\hline NC & $4.5 \pm 0.18$ & $4.00 \pm 0.20$ & $0.42 \pm 0.13$ & $0.37 \pm 0.01$ & $216.33 \pm 2.26$ & $227.83 \pm 1.35^{\$ \$}$ \\
\hline DC & $17.00 \pm 0.67$ & $19.97 \pm 1.52$ & $0.21 \pm 0.01$ & $0.03 \pm 0.02^{\# \# \# \$ \$}$ & $196 \pm 5.07$ & $168.5 \pm 7.91$ \#\#\#\$\$ \\
\hline Metformin & $15.85 \pm 1.24$ & $8.40 \pm 1.27^{* * \$}$ & $0.21 \pm 0.02$ & $0.29 \pm 0.01$ & $209.17 \pm 5.30$ & $195.17 \pm 9.37 \#$ \\
\hline AE (1000 mg/kg b.w.) & $16.95 \pm 0.58$ & $7.35 \pm 0.70^{* * * \$ \$ \$}$ & $0.19 \pm 0.02$ & $0.20 \pm 0.03$ & $203.83 \pm 3.96$ & $167.50 \pm 8.80^{\# \# \# \$ \$}$ \\
\hline AE (500 mg/kg b.w.) & $16.43 \pm 0.93$ & $8.35 \pm 1.42 * * \$$ & $0.19 \pm 0.02$ & $0.25 \pm 0.04^{\# \# * \$}$ & $206.5 \pm 3.37$ & $169.17 \pm 4.44^{\# \# \# \$ \$ ~}$ \\
\hline $\mathrm{AE}(250 \mathrm{mg} / \mathrm{kg}$ b.w. $)$ & $15.47 \pm 1.07$ & $16.00 \pm 2.86$ & $0.18 \pm 0.03$ & $0.18 \pm 0.01$ \#\#* & $199.67 \pm 3.51$ & 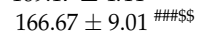 \\
\hline
\end{tabular}

\subsection{Effect on Lipid Profile}

Table 2 shows the serum levels of total cholesterol (TC), triglycerides (TG), high density lipoprotein (HDL) cholesterol, low density lipoprotein (LDL) cholesterol and the atherogenic index of plasma (AIP) of normal and STZ-induced diabetic rats. As compared with NC, significantly increased TG levels $(34.93 \%, p<0.05)$ in DC were not accompanied by significant changes in the levels of TC, HDL or LDL cholesterol. The administration of metformin to diabetic rats over the course of 12 days did not cause any significant changes in the serum lipid profile as compared to DC. On the other hand, AE, at the dose of $1000 \mathrm{mg} / \mathrm{kg}$ b.w., significantly decreased the levels of TG $(50.28 \%, p<0.01)$, with no significant changes in the levels of TC and HDL cholesterol as compared to DC. The doses of 500 and $250 \mathrm{mg} / \mathrm{kg}$ b.w. of AE showed comparable effects on the lipid profile; TC and TG levels were significantly decreased $(38.96 \%$ and $38.96 \%, p<0.05 ; 58.95 \%$ and $43.86 \%, p<0.05)$, and so was HDL cholesterol $(38.41 \%$ and $42.92 \%, p<0.05)$. AIP indicated a lower risk of cardiovascular disease in the diabetic rats treated with $\mathrm{AE}$ at the doses of $1000 \mathrm{mg} / \mathrm{kg}$ b.w. and $500 \mathrm{mg} / \mathrm{kg}$ b.w. (AIP values were 0.07 and 0.1 , respectively). 
Table 2. Effect of twice daily oral administration of different doses of AE for 12 days on the serum lipid profiles of normal and STZ-induced diabetic rats.

\begin{tabular}{cccccc}
\hline \multirow{2}{*}{ Treatment (mg/kg b.w.) } & \multicolumn{5}{c}{ Serum Lipid Profile (mg/dL) } \\
\cline { 2 - 6 } & TC & TG & HDL & LDL & AIP \\
\hline NC & $64.68 \pm 0.84$ & $44.92 \pm 3.20$ & $39.83 \pm 7.13$ & $20.58 \pm 1.26$ & 0.05 \\
DC & $61.76 \pm 4.17$ & $69.03 \pm 2.31^{\#}$ & $36.58 \pm 3.00$ & $11.39 \pm 1.63$ & 0.28 \\
Metformin (500 mg/kg b.w.) & $62.84 \pm 2.90$ & $66.21 \pm 5.90^{\#}$ & $37.32 \pm 4.22$ & $12.28 \pm 1.99$ & 0.25 \\
AE (1000 mg/kg b.w.) & $65.62 \pm 9.75$ & $34.32 \pm 3.78^{* *}$ & $29.2 \pm 3.00$ & $23.69 \pm 7.06^{* *}$ & 0.07 \\
AE (500 mg/kg b.w.) & $37.70 \pm 2.90^{* \#}$ & $28.34 \pm 3.00^{* *}$ & $22.53 \pm 1.72^{* \# \#}$ & $6.86 \pm 2.28$ & 0.1 \\
AE (250 mg/kg b.w.) & $37.70 \pm 3.99^{* \#}$ & $38.75 \pm 9.19^{*}$ & $20.88 \pm 2.25^{* \# \#}$ & $8.99 \pm 0.33$ & 0.27 \\
\hline
\end{tabular}

Data is expressed as mean \pm S.E.M., $n=6 .{ }^{*} p<0.05,{ }^{* *} p<0.01,{ }^{* * *} p<0.001$ versus DC. ${ }^{\#} p<0.05,{ }^{\# \# \#} p<0.001$ versus NC. TC, total cholesterol. TG, triglycerides. HDL, high density lipoprotein. LDL, low density lipoprotein. AIP, atherogenic index of plasma. S.E.M, standard error of the mean.

\subsection{Immunohistochemical Study of Insulin-Containing $\beta$-Cells of the Pancreas}

Insulin-containing $\beta$ cells refer to viable $\beta$-cells capable of secreting insulin, and are represented by dark brown granules. As can be seen in Figure 2, in NC, the islets of Langerhans showed a normal histological structure with insulin-expressing areas occupying mainly the central zone. In contrast, the islets of Langerhans in DC appeared to be shrunken and irregular in shape. All groups treated with $\mathrm{AE}$ at the doses of 1000, 500, and $250 \mathrm{mg} / \mathrm{kg}$ b.w. were observed to have distorted and smaller pancreatic islets as compared with NC. These groups, however, showed larger insulin-expression areas than those of DC, though the difference was statistically insignificant.
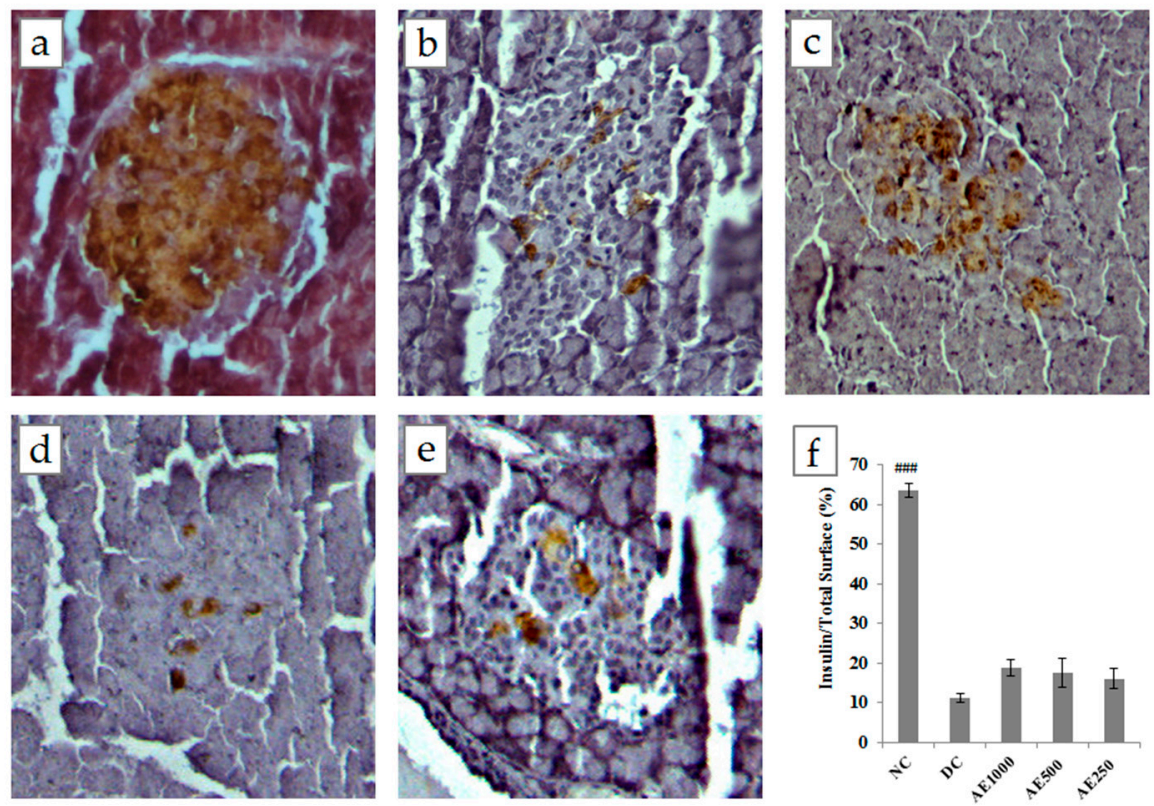

Figure 2. Immunohistochemistry staining of pancreatic $\beta$ cells after 12 days, twice daily oral treatment. (a) NC-intact Langerhans islets with insulin-containing area (dark brown) occupying mainly in the central zone; (b) DC-Langerhans islets appeared to be shrunk with significant reduction in the insulin-containing area; (c-e) AE (1000 mg/kg b.w., 500 mg/kg b.w., $250 \mathrm{mg} / \mathrm{kg}$ b.w., respectively) - Langerhans islets appeared to be distorted and smaller. These groups showed larger insulin-expressing areas than those in DC but were statistically insignificant; (f) The percentage of insulin-expressing areas in pancreatic islets. Values were expressed as mean \pm S.E.M $(n=10)$; \#\#\# $p<0.001$ versus DC. 


\subsection{Hepatoprotective Effect of $A E$}

The histological study of the liver revealed significant changes in the general histological organisation of the hepatic tissue between NC and DC (Figure 3). In NC, the hepatic lobular structure seemed to be normal with no red blood cell congestion in the central vein and the sinusoids. The polygonal hepatocytes appeared to be having single or polynuclei; no fat deposits in the centrilobular portions of the livers were detected. On the other hand, DC showed a red blood cell congestion in the portal vein system and the sinusoids, with the accumulation of micro droplets of fat in the centrilobular portion. Treatment with AE at the dose of $1000 \mathrm{mg} / \mathrm{kg}$ b.w. restored the histological appearance of the liver as hepatocytes and the central vein appeared to be normal. Meanwhile, the doses of 500 and $250 \mathrm{mg} / \mathrm{kg}$ b.w. resulted in better improvement of the liver histology as no congestion of red blood cells was noted in the central vein and sinusoids, as compared with DC. However, an accumulation of micro droplets of fat was still found with decrease amount.
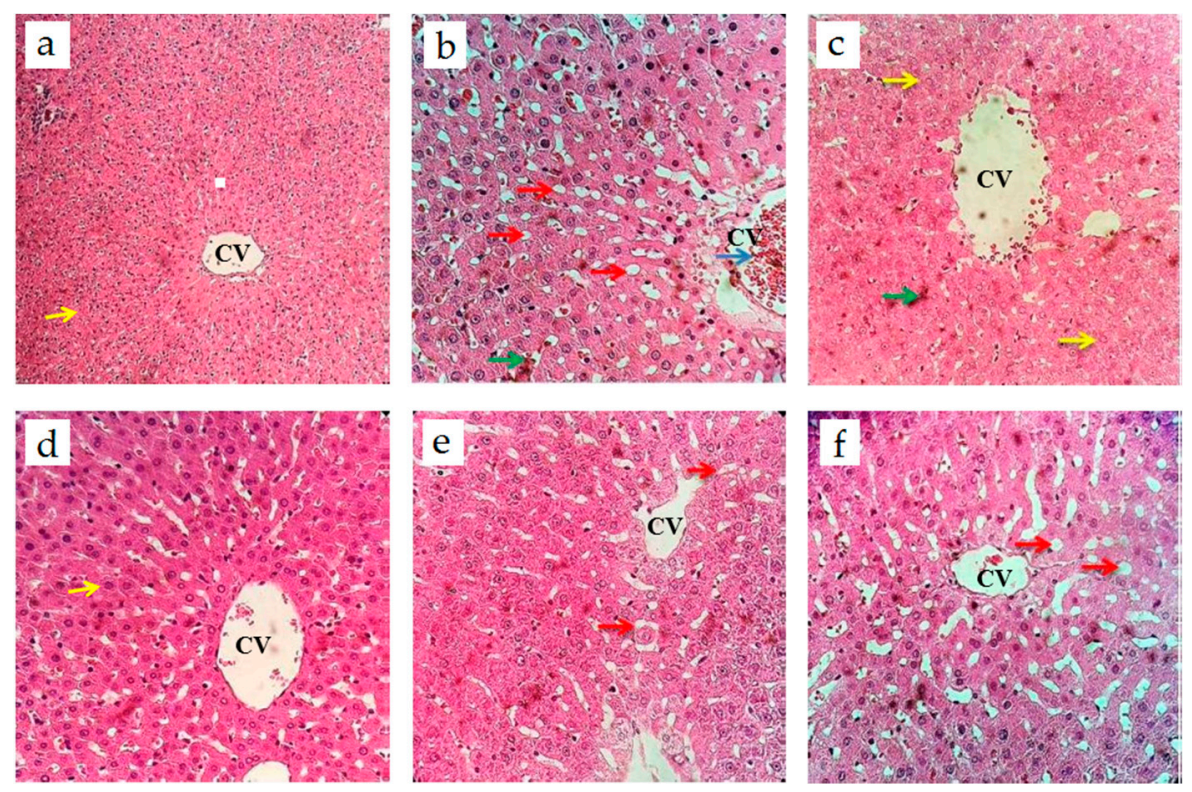

Figure 3. Histology of the livers of experimental rats after 12 days of twice-daily oral treatment with AE: (a) NC — the hepatic lobular cells and architecture seemed to be normal; (b) DC-Clear red blood cell congestion in the portal vein system (blue arrow) and sinusoids (green arrow), with the accumulation of micro droplets of fat in the centrilobular portion (red arrows); (c) Metformin (500 mg/kg b.w.) - Hepatocyte swelling (yellow arrow) and sinusoidal congestion (green arrow) with a decreased number of micro droplets of fat deposit; (d) AE (1000 mg/kg b.w.) -normal liver morphology with normal hepatocytes and a central vein; (e) AE (500 mg/kg b.w.) — decreased microvesicular fatty change (red arrow); (f) AE (250 mg/kg b.w.) - decreased fat micro droplets (red arrow). CV, central vein.

\subsection{Cytotoxicity Effect of AE on RIN-5F Cells}

$\mathrm{AE}$ at the concentrations ranging from $3.125 \mu \mathrm{g} / \mathrm{mL}$ to $100 \mu \mathrm{g} / \mathrm{mL}$ did not cause any cytotoxic effect to RIN-5F cells, indicating that the effect of $\mathrm{AE}$ on insulin secretion was not due to its cytotoxicity.

\subsection{Insulin Secretion Effect of AE on RIN-5F Cells}

As shown in Figure 4, glibenclamide $(0.988-98.8 \mu \mathrm{g} / \mathrm{mL})$ significantly stimulated the release of insulin from RIN-5F cells at the basal glucose concentration of $1.1 \mathrm{mM}$. At the concentrations of 6.25, 12.5 and $25 \mu \mathrm{g} / \mathrm{mL}$, AE produced similar stimulatory effects as glibenclamide, albeit rather weaker. No significant difference was seen in the stimulatory effect for those three applied doses. 


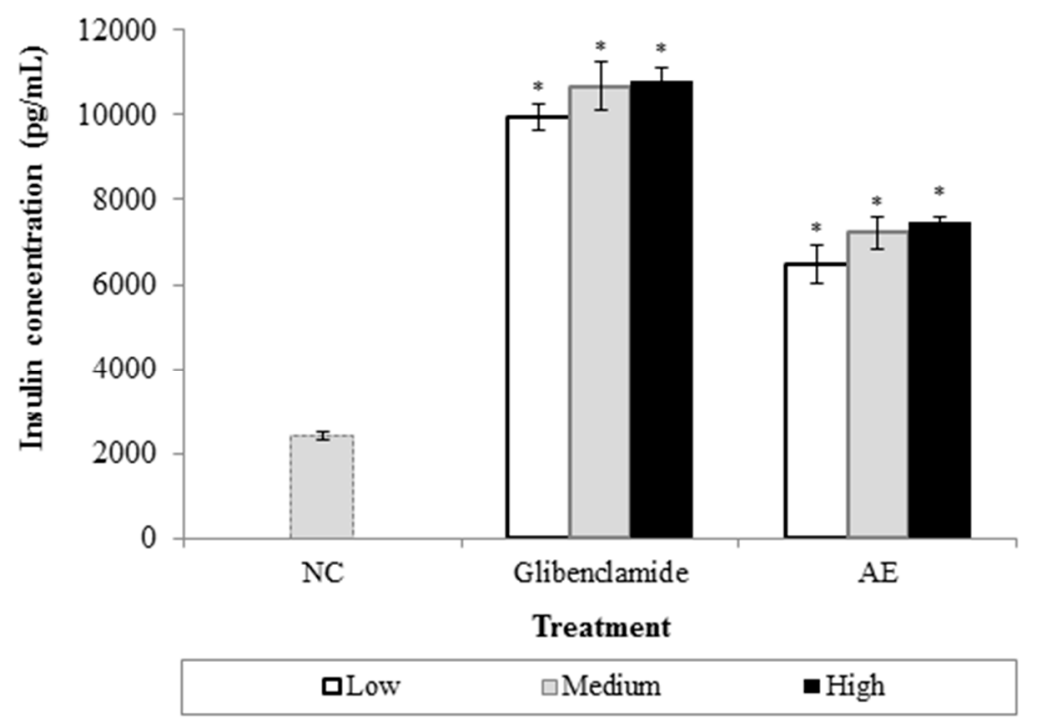

Figure 4. Effects of AE on insulin secretion by RIN-5F cells. Values are expressed as mean \pm S.E.M $(n=6)$. The concentrations of glibenclamide were determined as follows: low $(0.988 \mu \mathrm{g} / \mathrm{mL})$; medium $(9.88 \mu \mathrm{g} / \mathrm{mL})$, and; high $(98.8 \mu \mathrm{g} / \mathrm{mL})$; whereas for $\mathrm{AE}$, the range was as follows: low $(6.25 \mu \mathrm{g} / \mathrm{mL})$; medium $(12.5 \mu \mathrm{g} / \mathrm{mL})$, and; high $(25 \mu \mathrm{g} / \mathrm{mL}) .{ }^{*} p<0.05$ is significant as compared to NC.

\section{Discussion}

This study was conducted to evaluate the antihyperglycaemic effect of 12-day oral administration of AE (1000, 500, and $250 \mathrm{mg} / \mathrm{kg}$ b.w.) on STZ-induced diabetic rats. Further investigations focusing on the pancreas and liver were carried out in an attempt to understand the possible effect of AE on these two vital organs that are involved in glucose homeostasis. From the data presented in Table 1, it can be concluded that $\mathrm{AE}$ exerted a dose-dependent effect on serum glucose levels as the maximum reduction of blood glucose was observed in the diabetic rats treated with the highest dose (1000 $\mathrm{mg} / \mathrm{kg}$ b.w.), followed by those treated with 500 and $250 \mathrm{mg} / \mathrm{kg}$ b.w. Furthermore, AE-treated groups showed no significant differences in terms of weight loss, as compared to DC. Body weight loss which was observed in the untreated and treated diabetic rats might happen due to increased muscle wasting and loss of protein from tissues [22]. This finding is in agreement with Soltan and Shehata [23], as they reported no significant difference between the weights of rats treated with various types of vinegars as compared with DC. Moon et al. [24] studied the effect of persimmon vinegar on weight gain and reported the same outcome.

Hypercholesterolemia and hypertriglyceridemia are primary factors involved in the development of atherosclerosis and coronary heart disease-two of the secondary complications of diabetes [25,26]. STZ significantly increased TG levels with no significant changes in TC, HDL cholesterol and LDL cholesterol as compared with the levels shown in normal rats (Table 2). AE at the dose of $1000 \mathrm{mg} / \mathrm{kg}$ b.w. showed significant reduction in serum TG, but it did not ameliorate the levels of TC. Then again, as the dose was decreased to 500 and $250 \mathrm{mg} / \mathrm{kg}$ b.w., TG and TC levels were reduced. This finding could imply that lower AE concentrations produce better effects on the lipid profile. Taken together, the findings suggest that the observed hypolipidemic effect is not mediated by better glycaemic control.

Hypoinsulinaemia, one of the major characteristics of STZ-induced diabetic rats, occurs due to irreversible destruction of insulin-producing $\beta$ cells in the pancreatic islets of Langerhans [27]. Treatment with different doses of AE for 12 days showed significant improvement in serum insulin levels (Table 1), thus suggesting that the observed antihyperglycaemic effect of AE was due to its action at the pancreatic level by stimulating insulin secretion from viable $\beta$ cells (insulin secretagogue) and/or triggering the regeneration of pancreatic $\beta$ cells. Hence, the possible pancreatic effects of AE were 
further scrutinized through an immunohistochemical analysis of the pancreatic tissue. From the section presented in Figure 2, it could be concluded that almost all the insulin-positive areas in STZ-induced diabetic rats, treated and untreated, showed signs of degeneration and necrosis. Moreover, the areas of insulin-positive cells in these groups were significantly reduced as compared with normal rats. These conditions were presumed to coincide with a decrease in plasma insulin secretion and an increase in blood glucose levels. However, diabetic rats treated with AE (1000 and $500 \mathrm{mg} / \mathrm{kg}$ b.w.) showed a significant increase in serum insulin concentrations, which could be responsible for the improved blood glucose levels in these animals (Table 1). There are two possible explanations for this outcome. The bioactive compounds of AE might have acted by stimulating insulin secretion from viable $\beta$ cells that were not destroyed during STZ induction, while compounds present in AE further enhanced the effects of circulating insulin [28,29]. These actions were not necessarily accompanied by any structural recovery in pancreatic $\beta$ cells. This explains why there is no improvement in the insulin expression area of $\beta$ cells pertaining to the regeneration effect of $\mathrm{AE}$, as reflected in the immunohistochemical study of the pancreas. Several medicinal plants have been found to exert their hypoglycaemic activities via the stimulation of insulin secretion from pancreatic $\beta$ cells. Examples are Aloe vera, Gymnema sylvestre, and Hibiscus rosa-sinesis [30-32].

To clarify the possible effect of AE in stimulating insulin secretion from viable $\beta$ cells, the RIN-5F cell line was used. RIN-5F cell line is a cloned pancreatic $\beta$ cell derived from rat tumour islet cells. This cell line provides a model for in vitro study of the biology of pancreatic islet cells, including the mechanisms that control insulin secretion [33,34]. As depicted in Figure 4, AE stimulated insulin secretion even in basal glucose $(1.1 \mathrm{mM})$ conditions. A similar effect was seen in the glibenclamide-treated group. Thus, it could be hypothesized that AE's insulin stimulatory effect was mediated, in part, by its ability to regulate insulin secretion from $\beta$ cells. To test this hypothesis, a further study is required in order to pinpoint AE's effects on the depolarization of the $\beta$ cell membrane in terms of the opening and closure of ATP-sensitive $\mathrm{K}^{+}$and/or voltage-gated $\mathrm{Ca}^{2+}$ channels; the expression of proinsulin mRNA; and extracellular $\mathrm{Ca}^{2+}$ influx [35]. All these factors could contribute to insulin exocytosis from $\beta$ cells in the pancreas.

In addition to the insulin stimulatory effect, $\mathrm{AE}$ also produced a positive hepatoprotective effect. The liver plays a crucial role in glucose homeostasis. This role is due to its capability to control hepatic glucose production via two ways: The release of newly synthesized glucose in the blood stream during the fasting state; and the utilization and storage of glucose when glucose is elevated during the feeding state [36,37]. STZ administration causes substantial changes in the intracellular metabolism of most tissues, including the liver. Examples of such changes in the liver are fat deposition, the development of lesions, the congestion of portal vessels and sinusoids and the dilation of veins [38,39]. By using H\&E staining, significant histopathological changes were observed in the liver tissue of DC rats as compared with NC (Figure 3). DC rats exhibited several of those aforementioned histopathological abnormalities. Treatment with AE significantly enhanced the lobular architecture and the central vein in livers that were earlier affected by STZ induction. It seems that AE protects hepatocytes from the toxic effects of STZ. This finding, though inconclusive, suggests that Nypa fruticans Wurmb.'s AE can act as a hepatoprotective agent. Similar findings were observed by Halima et al. [40] and Omar et al. [16] when studying the effect of apple cider vinegar on the livers of diabetic rats.

The present findings ought to be considered in the context of several limitations. Though our histoarchitectural results indicated a hepatoprotective effect, all liver function parameters should be measured to confirm it, including aspartate aminotransferase (AST), alanine aminotransferase (ALT), alkaline phosphatise (ALP), albumin and bilirubin and the level of antioxidants enzymes, namely superoxide dismutase (SOD), catalase (CAT) and glutathione (GST). Further studies with longer observational durations are needed in order to confirm our findings. This may be especially required as NPV is a dietary ingredient that is commonly ingested on daily basis in some rural communities; and a shorter treatment period had previously been shown to precipitate no significant improvement of diabetic blood glucose levels [10]. Furthermore, the cell culture technique used in 
the present work employed a basal level of glucose concentration. It is possible that observations made using different concentrations of glucose could, in the future, provide further insight into AE's insulin-stimulatory effects.

\section{Conclusions}

In conclusion, these findings imply that constant consumption of NPV could bring positive effect on the pancreas and liver. Considering the close relationship of pancreas and liver with the progression of diabetes, NPV may provide a potential complementary alternative for the therapy of this metabolic disorder.

Acknowledgments: This work was supported by a research university grant (1001/PFARMASI/815080) of Universiti Sains Malaysia (USM) and fundamental research grant scheme (203/CIPPT/6711382) offered by Ministry of Higher Education, Malaysia. Furthermore, the authors express their appreciation to Puan Salmiah Hasan for supplying nipa palm vinegar.

Author Contributions: The authors' contributions are as follows: N.A.Y. conducted the experiment and drafted the manuscript. B.A.-H., K.N.A.R. and T.W. helped in collecting the data. D.R.A. interpreted the histological slides of pancreas and liver tissues. V.L. revised the paper. M.A. and M.Z.A. contributed reagents/materials/analysis tools. N.A.Y. and M.Z.A. designed the research and responsible for the final content. All authors read and approved the final manuscript.

Conflicts of Interest: The authors declare no conflict of interest. The founding sponsors had no role in the design of the study; in the collection, analyses, or interpretation of data; in the writing of the manuscript, and in the decision to publish the results.

\section{Abbreviations}

The following abbreviations are used in this manuscript:

$\begin{array}{ll}\text { AE } & \text { Aqueous extract } \\ \text { NPV } & \text { Nypa fruticans Wurmb. vinegar } \\ \text { DM } & \text { Diabetes mellitus } \\ \text { STZ } & \text { Streptozotocin } \\ \text { b.w. } & \text { Body weight } \\ \text { i.p. } & \text { Intraperitoneal } \\ \text { p.o. } & \text { Per oral } \\ \text { SD } & \text { Sprague-Dawley } \\ \text { MTT } & \text { 3-(4,5-dimethylthiazol-2-yl)-2,5-diphenyltetrazoliumbromide } \\ \text { NC } & \text { Normal control } \\ \text { DC } & \text { Diabetic control }\end{array}$

\section{References}

1. Ballali, S.; Lanciai, F. Functional food and diabetes: A natural way in diabetes prevention? Int. J. Food Sci. Nutr. 2012, 63, 51-61. [CrossRef] [PubMed]

2. Rudkowska, I. Functional foods for health: Focus on diabetes. Maturitas 2009, 62, 263-269. [CrossRef] [PubMed]

3. Boaz, M.; Leibovitz, E.; Dayan, Y.B.; Wainstein, J. Functional foods in the treatment of type 2 diabetes: Olive leaf extract, turmeric and fenugreek, a qualitative review. Funct. Foods Health Dis. 2011, 1, 472-481.

4. Mirmiran, P.; Bahadoran, Z.; Azizi, F. Functional foods-based diet as a novel dietary approach for management of type 2 diabetes and its complications: A review. World J. Diabetes 2014, 5, 267. [CrossRef] [PubMed]

5. Couturier, K.; Qin, B.; Batandier, C.; Awada, M.; Hininger-Favier, I.; Canini, F.; Leverve, X.; Roussel, A.M.; Anderson, R.A. Cinnamon increases liver glycogen in an animal model of insulin resistance. Metabolism 2011, 60, 1590-1597. [CrossRef] [PubMed]

6. Waite, N.; Lodge, J.; Hart, K.; Robertson, D.; Badley, E.; Burton, S. The impact of fish-oil supplements on insulin sensitivity. J. Hum. Nutr. Diet. 2008, 21, 402-403. [CrossRef]

7. Cumaoglu, A.; Rackova, L.; Stefek, M.; Kartal, M.; Maechler, P.; Karasu, C. Effects of olive leaf polyphenols against $\mathrm{H}_{2} \mathrm{O}_{2}$ toxicity in insulin secreting $\beta$-cells. Acta Biochim. Pol. 2011, 58, 45-50. [PubMed] 
8. Martirosyan, D.M.; Singh, J. A new definition of functional food by ffc: What makes a new definition unique? Funct. Foods Health Dis. 2015, 5, 209-223.

9. O'Keefe, J.H.; Gheewala, N.M.; O'Keefe, J.O. Dietary strategies for improving post-prandial glucose, lipids, inflammation, and cardiovascular health. J. Am. Coll. Cardiol. 2008, 51, 249-255. [CrossRef] [PubMed]

10. Yusoff, N.A.; Yam, M.F.; Beh, H.K.; Razak, K.N.A.; Widyawati, T.; Mahmud, R.; Ahmad, M.; Asmawi, M.Z. Antidiabetic and antioxidant activities of Nypa fruticans wurmb. Vinegar sample from malaysia. Asian Pac. J. Trop. Med. 2015, 8, 595-605. [CrossRef] [PubMed]

11. Yusoff, N.A.; Ahmad, M.; al Hindi, B.; Widyawati, T.; Yam, M.F.; Mahmud, R.; Razak, K.N.A.; Asmawi, M.Z. Aqueous extract of Nypa fruticans wurmb. Vinegar alleviates postprandial hyperglycemia in normoglycemic rats. Nutrients 2015, 7, 7012-7026. [CrossRef] [PubMed]

12. Ewald, N.; Kaufmann, C.; Raspe, A.; Kloer, H.; Bretzel, R.; Hardt, P. Prevalence of diabetes mellitus secondary to pancreatic diseases (type 3c). Diabetes Metab. Res. Rev. 2012, 28, 338-342. [CrossRef] [PubMed]

13. Leeds, J.; Forman, E.; Morley, S.; Scott, A.; Tesfaye, S.; Sanders, D. Abnormal liver function tests in patients with type 1 diabetes mellitus: Prevalence, clinical correlations and underlying pathologies. Diabet. Med. 2009, 26, 1235-1241. [CrossRef] [PubMed]

14. Levinthal, G.N.; Tavill, A.S. Liver disease and diabetes mellitus. Clin. Diabetes 1999, 17, 73.

15. Seok, H.; Lee, J.Y.; Park, E.M.; Park, S.E.; Lee, J.H.; Lim, S.; Lee, B.-W.; Kang, E.S.; Lee, H.C.; Cha, B.S. Balsamic vinegar improves high fat-induced beta cell dysfunction via beta cell abca1. Diabetes Metab. J. 2012, 36, 275-279. [CrossRef] [PubMed]

16. Omar, N.A.A.; Allithy, A.N.E.A.; El Sayed, S.M. Hepatoprotective and antidiabetic effects of apple cider vinegar (a prophetic medicine remedy) on the liver of male rats. Egypt. J. Hosp. Med. 2016, 62, 95-105.

17. Mohamad, N.E.; Yeap, S.K.; Lim, K.L.; Yusof, H.M.; Beh, B.K.; Tan, S.W.; Ho, W.Y.; Sharifuddin, S.A.; Jamaluddin, A.; Long, K. Antioxidant effects of pineapple vinegar in reversing of paracetamol-induced liver damage in mice. Chin. Med. 2015, 10, 3. [CrossRef] [PubMed]

18. Qiu, J.; Ren, C.; Fan, J.; Li, Z. Antioxidant activities of aged oat vinegar in vitro and in mouse serum and liver. J. Sci. Food Agric. 2010, 90, 1951-1958. [CrossRef] [PubMed]

19. Yam, M.F.; Ang, L.F.; Salman, I.M.; Ameer, O.Z.; Lim, V.; Ong, L.M.; Ahmad, M.; Asmawi, M.Z.; Basir, R. Orthosiphon stamineus leaf extract protects against ethanol-induced gastropathy in rats. J. Med. Food 2009, 12, 1089-1097. [CrossRef] [PubMed]

20. Mosmann, T. Rapid colorimetric assay for cellular growth and survival: Application to proliferation and cytotoxicity assays. J. Immunol. Methods 1983, 65, 55-63. [CrossRef]

21. Hassan, Z.; Yam, M.F.; Ahmad, M.; Yusof, A.P.M. Antidiabetic properties and mechanism of action of Gynura procumbens water extract in streptozotocin-induced diabetic rats. Molecules 2010, 15, 9008-9023. [CrossRef] [PubMed]

22. Cheng, D.; Liang, B.; Li, Y. Antihyperglycemic effect of Ginkgo biloba extract in streptozotocin-induced diabetes in rats. BioMed Res. Int. 2012, 2013, 162724. [PubMed]

23. Soltan, S.S.A.; Shehata, M.M.E.M. Antidiabetic and hypocholesrolemic effect of different types of vinegar in rats. Life Sci. J. 2012, 9, 2141-2151.

24. Moon, Y.-J.; Choi, D.-S.; Oh, S.-H.; Song, Y.-S.; Cha, Y.-S. Effects of persimmon-vinegar on lipid and carnitine profiles in mice. Food Sci. Biotechnol. 2010, 19, 343-348. [CrossRef]

25. Nelson, R.H. Hyperlipidemia as a risk factor for cardiovascular disease. Prim. Care Clin. Off. Pract. 2013, 40, 195-211. [CrossRef] [PubMed]

26. Forbes-Hernández, T.Y.; Giampieri, F.; Gasparrini, M.; Afrin, S.; Mazzoni, L.; Cordero, M.D.; Mezzetti, B.; Quiles, J.L.; Battino, M. Lipid accumulation in hepg2 cells is attenuated by strawberry extract through ampk activation. Nutrients 2017, 9, 621. [CrossRef] [PubMed]

27. Rakieten, N.; Rakieten, M.L.; Nadkarni, M.V. Studies on the diabetogenic action of streptozotocin (nsc-37917). Cancer Chemother. Rep. 1963, 29, 91-98. [PubMed]

28. Shanmugasundaram, E.R.B.; Gopinath, K.L.; Shanmugasundaram, K.R.; Rajendran, V.M. Possible regeneration of the islets of langerhans in streptozotocin-diabetic rats given Gymnema sylvestre leaf extracts. J. Ethnopharmacol. 1990, 30, 265-279. [CrossRef]

29. Fayed, T.; El-Missiry, M.A.; Emara, H.; El-Sayaad, N. Effect of Nigella sativa or fish oil supplementation in alloxan diabetic rats. J. Union Arab Biol. 1998, 9, 237-250.

30. Singh, L.W. Traditional medicinal plants of manipur as anti-diabetics. J. Med. Plants Res. 2011, 5, 677-687. 
31. Rao, M.U.; Sreenivasulu, M.; Chengaiah, B.; Reddy, K.J.; Chetty, C.M. Herbal medicines for diabetes mellitus: A review. Int. J. PharmTech Res. 2010, 2, 1883-1892.

32. Grover, J.; Yadav, S.; Vats, V. Medicinal plants of india with anti-diabetic potential. J. Ethnopharmacol. 2002, 81, 81-100. [CrossRef]

33. Gazdar, A.F.; Chick, W.L.; Oie, H.K.; Sims, H.L.; King, D.L.; Weir, G.C.; Lauris, V. Continuous, clonal, insulin-and somatostatin-secreting cell lines established from a transplantable rat islet cell tumor. Proc. Natl. Acad. Sci. USA 1980, 77, 3519-3523. [CrossRef] [PubMed]

34. Bhathena, S.J.; Awoke, S.; Voyles, N.R.; Wilkins, S.D.; Recant, L.; Oie, H.K.; Gazdar, A.F. Insulin, glucagon, and somatostatin secretion by cultured rat islet cell tumor and its clones. Proc. Soc. Exp. Biol. Med. 1984, 175, 35-38. [CrossRef] [PubMed]

35. Lee, S.-H.; Lim, S.-W.; Lee, Y.-M.; Lee, H.-S.; Kim, D.-K. Polysaccharide isolated from triticum aestivum stimulates insulin release from pancreatic cells via the atp-sensitive k+ channel. Int. J. Mol. Med. 2012, 29, 913. [PubMed]

36. Guo, X.; Li, H.; Xu, H.; Woo, S.; Dong, H.; Lu, F.; Lange, A.J.; Wu, C. Glycolysis in the control of blood glucose homeostasis. Acta Pharm. Sin. B 2012, 2, 358-367. [CrossRef]

37. König, M.; Bulik, S.; Holzhütter, H.-G. Quantifying the contribution of the liver to glucose homeostasis: A detailed kinetic model of human hepatic glucose metabolism. PLoS Comput. Biol. 2012, 8, e1002577. [CrossRef] [PubMed]

38. Degirmenci, I.; Kalender, S.; Ustuner, M.C.; Kalender, Y.; Gunes, H.V.; Unal, N.; Basaran, A. The effects of acarbose and Rumex patientia on liver ultrastructure in streptozotocin-induced diabetic (type ii) rats. Drugs Exp. Clin. Res. 2001, 28, 229-234.

39. Zafar, M.; Naqvi, S.N.; Ahmed, M.; Kaimkhani, Z.A. Altered liver morphology and enzymes in streptozotocin induced diabetic rats. Int. J. Morphol. 2009, 27, 719-725. [CrossRef]

40. Halima, B.H.; Sarra, K.; Houda, B.J.; Sonia, G.; Abdallah, A. Antihyperglycemic, antihyperlipidemic and modulatory effects of apple cider vinegar on digestive enzymes in experimental diabetic rats. Int. J. Pharmacol. 2016, 12, 505-513. [CrossRef] 